\title{
Catch Rate of Artisanal Fisheries, Percentage Abundance and Species Composition In Akpayafe River In Bakassi Local Government Area, Cross River, Nigeria.
}

\author{
*AJAH, Paul Onu, **ASUQUO, Peter Ene. \\ *Faculty of Oceanography, University of Calabar, Calabar, Nigeria. \\ ** Department of Zoology and Environmental Biology, University of Calabar, Calabar, Nigeria.
}

\begin{abstract}
Investigation on the catch rate of artisanal fisheries and species composition in Akpayafe River, Bakassi Local Government Area was carried out monthly from April 2009 - March 2010 to determine the catch rate of the fisheries in the river system as well as the relative abundance of the different fish species. A total of 23 fish species and 20 fish families were recorded. Ethmalosa fimbriata, Chrysichthys nigrodigitatus, Callinectes amnicola were dominant species with E. fimbriata being the most abundance species with 12694 individuals, C. nigrodigitatus with 957 then C. amnicola with 852 individuals. Fish abundance was generally high in April, May and December 2009 than other months. High populations of 3759, 2664 and 2511 individuals respectively were recorded in December, April and May with higher catch rates observed in May (69.98kg/day/boat) and July (21 kg/day/boat) but least in March (6.7kg/day/boat). E. fimbriata was the most abundant species and Hydrocynus brevis was the least abundant during the survey.
\end{abstract}

Keywords: Relative abundance, catch rate, river systems

\section{Introduction}

Universally, fishing is declared as one of the commonest and oldest occupation of man. Millions of people in the world over get engaged in the fishing activity of processing, marketing, storage and distribution of fisheries products. Fishing techniques range from the traditional methods to trawl-fishing which is a more advanced, profitable and sophisticated method.

Nigeria has vast potentials for fisheries development, being endowed with a minimum of $46,300 \mathrm{~km}^{2}$, and Exclusive Economic Zone (EEZ) of area of 210, $900 \mathrm{~km}^{2}$ and inland area of 12.5 million ha (Anko and Eyo 2003). The current production level of 400,000 metric tons is at a $50 \%$ deficit to meet Nigeria's fish need per annum of at least 1.5 million metric tons despite the huge endowment. Okorie (2003) observed that the bulk of fish production comes from the artisanal sector but because local production is inadequate to meet our demand, Nigeria imports about $49.5 \%$ of her fish need.

The Nigerian coastal waters contain numerous fisheries resources (Ita 1993, Ajah 2002, Odo et al 2009, Edward 2012) and Akpayafe River in Bakassi local government area forms a part of a higher level of biodiversity supporting a wide variety of fish species. The fish yields of most Nigeria inland waters are generally on the decline (Jamu and Ayinla 2003). The decline of these fisheries has been attributed to a wide range of causes ranging from inadequate management of the fisheries resources to environmental degradation of the water bodies. For sustainable exploitation of these resources, a crucial management tool is to have a comprehensive understanding of the ichthyo faunal composition of the water bodies. The freshwater food fishes found in Nigeria are about 268 different fish species (Lévesque et al. 1992). They inhabit over 34 well-known freshwater bodies (rivers, lakes, and reservoirs) which constitute about $12 \%$ of Nigeria's total surface area put at 94,185,000 ha (Ita 1993). Boulenger (1916) published a list of African freshwater fishes to include 976 species, referable to 185 genera and 43 families; whereas, Welman (1948) produced a list of 181 species of fish that could be found in Nigeria inland waters such as 28 and 22 species respectively in Kaduna and Sokoto-Rima Rivers. Odo et al (2009) found 52 fish species belonging to 17 families: 171, 236, and 169 individuals at Ogurugu, Otuocha, and Nsugbe stations respectively. Cross River, Ogun, and Osun Rivers have 39, 23, and 23 fish species respectively. Ajah (2002) found a total of 1338 fish from 23 families and 26 genera representing 30 species in the Great Kwa River, Nigeria. Ita (1993) gave an estimate of 230 species fish from the rivers of Nigeria. For sustainable exploitation of these fishery resources in the river basin, a crucial management tool would be a comprehensive understanding of the ichthyofaunal composition of the water bodies.

This study aims at determining the total fish species, the relative abundance and catch levels of the different fish species in Akpayafe River. 


\section{Description of the Study Area}

\section{Materials And Methods}

Bakassi peninsula is triangular in shape, covers a land mass of $650 \mathrm{~km}^{2}$ and lies between latitudes $40^{0} 26^{1}$ and $40^{0} 50^{1}$ north of the equator and longitudes $80^{0} 30^{1}$ and $90^{0} 08^{1}$ east of the Greenwich Meridian. It is a piece of sparsely populated land in the corner of the Gulf of Guinea. The peninsula is bordered in the North and west by Akpayafe River being the main area of study. To the east is Rio Del Rey estuary and south, the Gulf of Guinea. The warm east following Guinea current meets the Benguela current at the peninsula thus, making the area a very fertile fishing ground with abundant species of fishes and shrimps and one of the biggest suppliers of aquatic food in the sub region. In Akpayafe River, there are two major beaches for fish landings just beside the Ikang major market. Tidal incursion occurs twice a day: morning and evening causing the beach to be always submerged at high tides. The River located in a village called Ikang in Bakassi Local Government Area in Cross River State.

Sampling Regime: Every month, 6-7 boats went into operations but only four boats were randomly sampled in the first and last week of each month. Samples of the different fish species in the catch of the artisanal fisheries landing in Ikang beach market were collected fortnightly. The survey lasted for one year covering the two seasons (dry and wet) of the year. Data were collected by first identifying, then counting and lastly recording the different fish species found in a particular boat landing at the beach. The weights of all the fish species were measured in kilograms using the spring balance. The fishes caught were identified to species levels before measurement using the following keys (Holden and Reed 1978; FAO 1990).

\section{Analysis of Samples}

The following weight measurements were carried out:

$\%$ abundance by weight $=\underline{\text { Weight per month }} \times 100$

Total weight per annum

$\%$ abundance by number $=$ Number per month $\quad x 100$

Total number per annum

\section{Results}

During the 12 months survey period in Akpayafe River that spanned from April 2009 to March 2010, a total of 16,413 individuals belonging to 23 fish species and 20 families were recorded (table 1). Every month, 6-7 boats went into operations but only 4 boats were randomly sampled in the first and last week of each month (table 1). Ethmalosa fimbriata was the most abundant species with 12,692 individual while Hydrocynus brevis was the least abundant species with only five individuals. Hepsetus odoe and Scomberomorus tritor had the same population of 116 individual each during the sampling period. Species distribution was observed to increase between April, May and November while most species started disappearing in July, August and September. Fluctuation in species composition and abundance were observed in June, October, December 2009, and January to March 2010. High population densities of E. fimbriata were observed in April, May November, December 2009 and March 2010 being the dry months. Moreover, the population of E. fimbriata experienced some decrease in rainy months of June, July and August. In July no individual E. fimbriata was caught rather the second most abundant species- Chrysichthys nigrodigitatus- had 957 individuals (table2). The catches per month showed that the month of May had the highest biomass of $279.7 \mathrm{~kg}$ followed by July and April with $204 \mathrm{~kg}$ and $139 \mathrm{~kg}$. During the fishing operations, a maximum of two fishers per canoe was always observed throughout the study period. Varying number of boats were observed in each month of sampling. However, October recorded the highest number of 21 boats actively involved in fishing activities followed by August with six, then September, December and March with five boats each while January and February recorded three boats each (table I). The monthly catch rates (table 1) showed that May had the highest catch of $279.9 \mathrm{~kg}$ followed by July, April, June, September and March with $204 \mathrm{~kg}, 129 \mathrm{~kg}, 129 \mathrm{~kg}, 109 \mathrm{~kg}$ and $34 \mathrm{~kg}$ respectively

Table 1: Total Catch Rate Per Month, Catch Per Unit Effort, Number Of Boat, Percentage Abundance and Total Weight of all species for the sampling period.

\begin{tabular}{|l|l|l|l|l|l|l|}
\hline Month & $\begin{array}{l}\text { No. of } \\
\text { Boats }\end{array}$ & $\begin{array}{l}\text { Total Catch } \\
(\mathrm{Kg})\end{array}$ & $\begin{array}{l}\text { Total number } \\
\text { caught }\end{array}$ & $\begin{array}{l}\% \\
\text { Abundance }\end{array}$ & $\begin{array}{l}\text { Catch Per Unit Effort } \\
(\text { Cpue)(kg/day) }\end{array}$ & $\begin{array}{l}\text { Catch Rate Per Boats/Day } \\
\text { (kg/day/boat) }\end{array}$ \\
\hline April & 4 & 139.5 & 2664 & 16.55 & 34.8 & 34.88 \\
\hline May & 4 & 279.9 & 2511 & 15.60 & 69.9 & \multicolumn{2}{|c|}{69.98} \\
\hline June & 5 & 109 & 1076 & 6.68 & 21.7 & 21.8 \\
\hline July & 4 & 204 & 313 & 1.94 & 51.0 & 51 \\
\hline Aug & 6 & 72.5 & 441 & 2.74 & 12.0 & 12.1 \\
\hline Sept & 5 & 129.5 & 485 & 3.01 & 25.9 & 25.9 \\
\hline Oct & 21 & 81 & 976 & 6.06 & 3.84 & 3.86 \\
\hline Nov & 4 & 86.2 & 1478 & 9.18 & 21.5 & 21.6 \\
\hline Dec & 5 & 95.0 & 3759 & 23.35 & 19.0 & 47.5 \\
\hline Jan & 3 & 46.3 & 632 & 3.93 & 15.4 & 23.2 \\
\hline Feb & 3 & 42.0 & 470 & 2.91 & 14.0 & 14 \\
\hline March & 5 & 33.5 & 1296 & 8.05 & 6.7 & 6.7 \\
\hline Total & $\mathbf{1 1 4}$ & $\mathbf{1 3 1 8}$ & $\mathbf{1 6 1 0 1}$ & & $\mathbf{2 9 4 . 8 4}$ & $\mathbf{3 3 2 . 5 2}$ \\
\hline
\end{tabular}

NB: every month had two fishers. 
Catch Rate Of Artisanal Fisheries, Percentage Abundance And Species Composition In Akpayatt

Table 2: Total Species Abundance, Weight and Percentage Occurrence between April 2009 and March 2010.

\begin{tabular}{|c|c|c|c|c|}
\hline Species & Family & Total Abundance & Weight (kg) & $\%$ Occurrence \\
\hline Ethmalosa fimbriata & Clupeidae & 12694 & 225 & 77.34 \\
\hline Pellonula leonensis & Clupeidae & 6 & 1.6 & 0.0366 \\
\hline Illisha Africana & Clupeidae & 15 & 3.5 & 0.0913 \\
\hline Callinectes amnicola & Portunidae & 852 & 47 & 5.191 \\
\hline Hepsetus odoe & Hepsetidae & 16 & 6 & 0.097 \\
\hline Sphyraena spp & Sphyraenidae & 131 & 33 & 0.798 \\
\hline Pomadasys jubeline & Pomasydae & 66 & 22 & 0.402 \\
\hline Oreochromis niloticus & Cichlidae & 180 & 54 & 1.097 \\
\hline Lates niloticus & Centropimidae & 55 & 22 & 0.335 \\
\hline Cynoglosus senegalensis & Cynoglossidae & 118 & 29 & 0.719 \\
\hline Psettias sebae & Monodactylidae & 39 & 5.3 & 0.238 \\
\hline Polydactylus quadrifilis & Polynemidae & 273 & 104 & 1.663 \\
\hline Lepturus trichiurus & Lepturiidae & 52 & 10.2 & 0.317 \\
\hline Caranx hippos & Carangidae & 49 & 34 & 0.299 \\
\hline Eleotris deganensis & Eleopidae & 52 & 9.5 & 0.317 \\
\hline Mugill cephalus & Mugilidae & 408 & 61 & 2.486 \\
\hline Lutjanus spp & Lutjanidae & 54 & 33 & 0.091 \\
\hline Pseudotolithus elongatus & Scianidae & 118 & 24 & 0.719 \\
\hline Chrysichthys nigrodigitatus & Bagridae & 957 & 515 & 5.831 \\
\hline Nematopalaemon hastatus & Potaemonidae & 250 & 0.1 & 1.523 \\
\hline Scomberomorus tritor & Scombridae & 16 & 1.0 & 0.097 \\
\hline Hydrocynus brevis & Characidae & 5 & 1.1 & 0.030 \\
\hline Icthyborus morodi & Characidae & 7 & 15.0 & 0.043 \\
\hline TOTAL & & 16,413 & $1,256.3$ & 100 \\
\hline
\end{tabular}

\section{Discussion}

The result of the survey of fisheries in Akpayafe River of 23 species belonging to 20 families indicates good species diversity. Our study showed that Ethmalosa fimbriata was the most abundant species followed by Chrysichthys nigrodigitatus. It was observed that the total population of all the fish species sampled was high within the following 6 months: March, April, May, June, November, and December. Ajah (2002) had more catches $(52 \%)$ in Great Kwa River during the dry season than the rainy season (48\%). In Akpayafe River, fish landings were largely dependent on the tidal pattern and fish catch were dominant during the ebb tide than at floodtides. Fishermen and those engaged in fishing activities usually returned to the shores between the hours of 7.00 a.m-11.30 a.m before afternoon when there will be turbulent mixing and the generation of land-sea breeze (Asuquo, 1999). This period of high fish population also had no sea-land breeze motion which induced the activeness and concentration in fishing activities as the case may be. Moreover, fish abundance in this month might have been as a result of decrease in water current which enabled fish to undergo normal movement (Moyle 1994). Allison and Okadi (2009) related poor species diversity to human activities such as dredging and water pollution from petroleum products occasioned by barges, tugs and other river crafts. The impact of human activities on species richness has also been reported by Kone et al. (2003) in the Go River (Ivory Coast) and Gratwicke et al. (2003) in the Upper Mangame River, Zimbabwe. By implication, calmer water bodies lead to enhanced nutrient aggregation for the aquatic organisms including fish. Lasker (1975) mentioned that a threshold number of particles are needed for the successful first feeding of anchovy larvae. Likewise, a stable water column is necessary to allow aggregation of larval food organism and formation of dense concentration above the threshold to be exploited. Thus in years when water column is stable and dense food concentration is formed; more fish larvae will survive leading to a large year class. Hence some species were able to obtain steady presence and availability of nutrition through aggregation process and consequently get entangled by fishers. As earlier stated Ethmalosa fimbriata was the most abundant but not in terms of body weight but numerically. E. fimbriata's total population was highest followed by C.Arysichthys nigrodigitatus (estuarine catfish). Ethmalosa was found throughout all the months of sampling although having fluctuations in their population during rainy seasons especially in August, October and November. There was a clear indication that this fish species tolerated salt water environment and the period of heavy rainfall which will as well cause some dilution in its environment caused this fish to travel out of the environment during this period. An investigation on the relationship between the hydro climatic parameters (rainfall and flood index) and the catch, stock abundance and recruitment of the catfish C.Arysichthys nigrodigitatus (Bagridae) and bonga, E.thmalosa fimbriata show that the linear relationship exist between the inter annual variations in the hydro régime and the yearly fluctuations in the catch and population structure of some coastal and estuarine fishes, holds true for the catfish C. nigrodigitatus, but not for Bonga, E. fimbriata-(Moses 2004). Ama-Abasi et al (2004) on the dynamics of the exploited population of E.thmalese fimbriata in Cross River estuary and adjacent gulf of Guinea revealed that eggs of E. fimbriata were abundant in water in the period of February due to high temperature and reproductive activities and that the stock of E. fimbriata was over fished based on the yield per 
recruit analysis. Using the von Bertalanfty growth function, $\mathrm{K}=0.90$, water point $(\mathrm{wp})=0.1$ signifies that growth slowed down in February which was attributed to high temperature and reproductive activities (Ama-Abasi et al, 2003).

Generally, it is noted that Bonga spawn in the ocean unlike Chrysichthys nigrodigitatus which were always found in the estuary year in year out. Bonga's juveniles move into the estuary between December and April according to studies on the migrating pattern of Ethmalosa fimbriata thus exemplifying why $70 \%$ of the adult female specimen and 5\% of the males caught during this period had mature gonads. It was observe that the population of E.thmalesa fimbriata was much in April with 2664 individuals. It extended to May with 2511, December with 3759 individuals but most especially the juveniles of this species where dominant few (133 adult) individuals seen in April. All these months were months of dry season which maintained the salinity in the River. The population gradually reduced towards the period of rainy season when the River began to get diluted by rain waters. Unlike the Bonga which increased and decreased in population in all the months of the survey, C.Arysichthys nigrodigitatus had an average population throughout the study period. Ajah (2002) witnessed more catches during the dry season. Ita (1993) observed that fish weight in the River Tiga (Kanu), Bakolari reservoir (Sokoto), River Rima (Sokoto) and Cross River all in Nigeria, was not dependent on abundance of the fish species. According to him most of the individual fish species though more in number, did not show a corresponding increase in weight some species with fewer individuals were reported to have higher weights than those with higher individuals. Ita (1993), provided a typical case in point when two members of the family clariidae weighed $1.10 \mathrm{~kg}$ while only one member of the family malapteridae weighed $5.70 \mathrm{~kg}$ from the same water body (River Tiga). A looking at study site here in Bakassi (Akpayafe River) revealed that $E$. fimbriata with a total population of 12694 individuals weighed $255.0 \mathrm{~kg}$ but $C$. nigrodigitatus with an average population of 957 individuals weighed $515.0 \mathrm{~kg}$. Likewise individuals of $C$. nigrodigitatus weighed $6.0 \mathrm{~kg}$ but a 200 individual of E. fimbriata weighed 3.0kg. Conversely, comparing the 2 species, we can draw a conclusion that the abundance of some fish species may not necessarily relate with weight.

According to Ita (1993) a particular fish species may be abundant but has lesser total weight depending however on the size ranges or classes of the exploited species. Few numbers of individuals which are of higher class size could weigh more than several smaller or lesser sized individuals. This was the observation recorded in July during which a total of 313 individuals that weighed $204 \mathrm{~kg}$ while in December a total of 3759 individuals weighed $95.0 \mathrm{~kg}$. A linear relationship existed between the fishery biodiversity and plankton community (Ajah 2002). The distribution of fish species by family showed that most of the fish species were caught in May with Ethmalosa fimbriata having a population of 2511 individuals due mainly to the balanced hydrological conditions in the river in May. The clupeid E. fimbriata is abundant along the coast of western Africa. It is estuary dependent and tropically distributed from Mauritania to Angola (Charles 1982; Lévesque et al, 1990). It is the most abundant fish species by both number and biomass's and heavily exploited by small scale fishing. (Durand et al 1982). Bonga had maximum of $40 \mathrm{~cm}$ in length (Bellemaus et al, 1988). Spawning of the Bonga is revealed to take place in waters of salinity greater than 5 percent. The young stay in the hatching area for months to attain a length of $6 \mathrm{~cm}$ before moving into estuarine or lagoon. The salinity influence on the growth in the early life of three West African fish species (Bonga, Sarotherodon and Tilapia guinesis) was studied using the width of micro structure in the otoliths and migratory behaviour of the individual species. The results showed that salinity has different influences on the growth of each species. Bonga had the highest growth during the first 180 days in the fresh waters indicating growth inhibition in the hyperhaline areas. Catch rates were observed to vary during the sampling period. In terms of weight, May catches recorded the highest catch. The variation observed in catch rate during the study period might have been due to fish availability, functionality of fishing gears and the number of fishing boats which actively involved in fishing activities. Ajah (2002) observed that fish catch increased with increase in salinity, plankton production and nutrient load.

\section{Summary And Conclusion}

Species composition and catch-rate of artisanal fisheries in Akpayafe River Bakassi local government area investigated between April 2009 and March 2010 showed that Ethmalosa fimbriata, Chrysicthys nigrodigitatus had peak catches during the survey. E.thmalosa fimbriata had a total population of 12,694 individuals; $C$. nigrodigitatus had a total of 957 individuals. Pellonula leonensis had the least population with only 6 individuals. Variation in fish species was noticed during the course of the survey. There was a sharp increase in catch rate in April, May, June and July with steady decrease in March. December had the highest population of 3,3759 individuals.

Factors such as migration, predators and an active involvement of fishermen in fishing activities leading to over fishing may be linked to the low catch rates in the affected months. Moreover, other environmental factors such temperature and climate change may also be linked with such low catch rates during such months. On the other hand the abundance of most species like Chrysichthys nigrodigitatus and Ethmalosa fimbriata may be linked to upstream migration for spawning purpose during which they are then intercepted by 
fishers. Fish abundance in March, April, May, June, November and December may be attributed to factors such as improved primary productivity, increased number of fishing boats and the number and biomass of individual species that have been naturally recruited into the standing stock. Months with noticeable decrease in the population of most species, could be due to the unfavorable conditions in the environment at that moment resulting in the disappearance of some species and family. In this work, it was observed that in July being a rainy month, no Bonga was found throughout the month. Recent studies proved that juveniles of bonga moved into the estuary but they moved out during raining season as a result of dilution. The same goes for C.hrysichthys nigrodigitatus. Finally the decline in abundance in July, August, September, January and February might have been as a result of most of the adult species migrating for spawning. To avoid the collapse of the fishery, a reduction of the fishing effort by directing the communities around the estuary to non fishing occupation is recommended. Moreover in other to prevent over exploitations, we recommend protection of the stock, firstly, by mesh size restriction and limiting catches by restricting fishing effort. Although it has been argued that the dangers of over fishing are exaggerated because the fishing industries are inherently self regulating. If over fishing occurs, earnings and profits will fall, boats are laid up and men will leave the industry, the fishing intensity reduces and the stock are able to recover (Tait and Dipper 1998)

\section{References}

[1]. Ajah, P.O. (2002). Fisheries biodiversity and plankton community of the Great Kwa River, Nigeria. Indian Hydrobiology, 5(2):8596.

[2]. P.O. Ajah \& S.A. Udoh (2012). Food and feeding habits, condition factor and length-weight relationships of Mugil cephalus and Pseudotolithus elongatus in Cross River Estuary, Cross River State, Nigeria. Tropical Freshwater Biology, 21 (2): 59 - 70.

[3]. Allison, M.E and D. Okadi (2009). Species Distribution and Abundance in the Lower Nun River, Niger Delta, Nigeria. Journal of Fisheries International, 4(1): 13-18

[4]. Ama-Abasi, D.E; U.I. Enin \& S. Holzloehner (2003). The Dynamics of The Exploited Population Of Ethmalosa fimbriata In Cross River Estuary And Adjacent Gulf Of Guinea. Fisheries Research, 68(1-3): 225-235.

[5]. Ama-Abasi. D., Holzloehner. S., and U. Enin., (2004). The dynamics of the exploited population of Ethmalosa fimbriata (Bowdich, 1825, Clupeidae) in the Cross River Estuary and adjacent Gulf of Guinea. Fishery Research, 68, 225-235.

[6]. Anko, E.O. \& A.A. Eyo, (2003). Fisheries development in Nigeria with special reference to Cross Rivers state. Proceeding of the 16th Annual Conference of Fisheries Society of Nigeria (FISON). Maiduguri, $4^{\text {th }}-9^{\text {th }}$ November 2001. In: Eyo, A.A and E.A. Ajao (Eds.). FISON P.O. Box 2607 Apapa Lagos, Nigeria. Pp. 303-311.

[7]. Asuquo, F.E. (1999). Physcio Chemical Characteristics and Anthropogenic Pollution of the Surface Water of Calabar River, Nigeria. Global Journal of Pure and Applied Science, 5(4): 595-600.

[8]. Boulenger, G.A (1916) Catalogue Of The Fresh Water Fishes Of Africa in the British museum.(natural history) 4: 392

[9]. Charles, D. (1982). Biology of Ethmalosa fimbriata and Fish Diversity in Multi polluted Environment. Journal of Marine Science, 2: $259-267$

[10]. Durand,B, Guyonnet, C. Aliaume, J. Albaret, C. Casellas, A. Zebi, G. Lasserre, T. \& A. Dochi (1982). Biology of Ethmalosa fimbriata. Journal of Marine Science, 60: 259-267.

[11]. Edward, J.B. (2012). Evaluation of the Fisheries Potentials of Egbe Reservoir, Ekiti State, Nigeria. Greener Journal of Biological Sciences ISSN: 2276-7762 Vol. 3 (7), pp. 260-267, September 2013.

[12]. Food and Agricultural Organization (FAO) (1990). Field Guide to the Commercial Marine Resources of the Gulf of Guinea. FAO species Identification Sheets for Fishery Purposes. FAO Regional Office For Africa. FAO Rome

[13]. Gratwicke, B., Marshall, B.E. \& T. Nhiwatiwa (2003). The distribution and relative abundance of stream fishes in the upper management river Zimbabwe in relation to land use pollution and exotic predators. African Journal of Aquaculture, 28: 25-34

[14]. Holden, M. \& W. Reed (1978). West African Freshwater Fish. Longman Group Ltd, London.

[15]. Ita, E.O. (1993). Inland Fisheries Resources of Nigeria. CIFA Occasional Paper. No.20 FAQ, Rome, D/T 1230 120pp.

[16]. Jamu, D.M and O.A. Ayinla (2003). The Fish Fauna of Anambra River Basin. International Journal Of Tropical Biology, 57(12):177-186

[17]. Kone, T., Teugels, G.G. Douba, V. Goorebi G. \& E.P. Kouamelan, (2003). First data on the inventory and the distribution of the ichthyofauna of a small African Western Coast Basin River Ivory Coast. Cybium, Intl. Newspaper of Ichthyology, 27pp.

[18]. Lasker, R. (1975). Field criteria for survival of anchovy larvae.The relation between chlorophyll layers and successful first feed. Fish Bulletin, U.S, 75:453-462.

[19]. Lévesque, C., D. Pangy \& G.G. Teugel (1992). Fish Fauna in Anambra River. Pp177-186

[20]. Moses, B.S. (2004), Influence Of Hydro Regime Catch Abundance And Recruitment Of Chrysichthys nigrodigitatus And Ethmalosa fimbriata. Journal of Environmental Biology of Fishes, 61(1): 234-256.

[21]. Moyle, N. (1994). Fish Communities. Indicators of Ecosystem Health. Academic Press, New York, 100.pp

[22]. Odo, G.E., Didigwu, N.C. \& J.E. Eyo (2009). The fish fauna of Anambra river basin, Nigeria: species abundance and morphometry Rev. Biol. Trop. (Int. J. Trop. Biol. 57 (1-2): 177-186.

[23]. Okorie, P.U., (2003). Nigeria fisheries at a time of economic paradigm shift. Proceeding of the 18th Annual Conference of the Fisheries Societyof Nigeria (FISON), Apapa Lagos, Nigeria.12-21pp. Tait, R.V and Dipper, F. A (1998). Elements of Marine Ecology, Pp 369-370.

[24]. Welman J.B. (1948). Preliminary survey of the Freshwater Fisheries of Nigeria. The Government Press, Lagos. 40pp. 